\title{
DOI: https://doi.org/10.24297/jap.v20i.9161
}

\section{Effect of the modification structure for Newton's metal on some its properties for industrial applications}

\author{
Eman Kashita
}

Educational Services, Qassim University, Ministry of High Education, Kingdom of Saudi Arabia

\begin{abstract}
Newton's metal is important for industrial applications that is the reason for studying the effect of modified structure of it's on mechanical and thermal properties. Microstructure, mechanical properties such as elastic modulus Vickers hardness, internal friction and melting temperature of $\mathrm{Bi}_{50} \mathrm{~Pb}_{34} \mathrm{Sn}_{16}, \mathrm{Bi}_{50} \mathrm{~Pb}_{28} \mathrm{Sn}_{22}, \mathrm{Bi}_{50} \mathrm{~Pb}_{22} \mathrm{Sn}_{28}$ and $\mathrm{Bi}_{50} \mathrm{~Pb}_{16} \mathrm{Sn}_{34}$ alloys have been studied and analyzed.

$X$-ray analysis of these alloys show that, it contained different phases with formed a solid solution. Elastic modulus variable decrease, melting temperature varied, internal friction and Vickers hardness increased due to modified Newton's metal $\left(\mathrm{Bi}_{50} \mathrm{~Pb}_{31.2} \mathrm{Sn}_{18.8}\right)$ alloy.
\end{abstract}

Key words: - Vickers hardness, internal friction, elastic modulus, melting temperature, structure

\section{Introduction}

Fusible alloys have low melting points compositions as bismuth, lead, tin, cadmium, or indium, which used in many applications such as fusible element in safety devices [1-3] and alarms, radio-opaque contrast medium in $\mathrm{x}$-ray, solder and nuclear medicine as a shielding block [4]. Microstructure, thermal parameters, internal friction, wettability and electrochemical corrosion behavior for bismuth- tin based alloy, Bi30Sn50Sb10Al5Zn3Cu2, Bi25Sn61Sb5Zn4Al3Ag2, and Bi20Sn60Sb7Al5Zn3Cd3Cu2 alloys were studied by different experimental techniques. The results show that, properties for $\mathrm{Bi}-\mathrm{Sn}$ alloys based changed after adding alloying elements $[5,6]$.

Several studies [7- 16] covered structure, mechanical and thermal properties of bismuth based or tin based alloys with studying the effect of alloying elements on their properties. The aim of this research is to study the effect of modified structure on mechanical and thermal properties of bismuth based alloys.

\section{Materials and methods}

Bismuth, tin and lead metals with purity more than $99.9 \%$ were used to prepare $\mathrm{Bi}_{50} \mathrm{~Pb}_{34} \mathrm{Sn}_{16}, \mathrm{Bi}_{50} \mathrm{~Pb}_{28} \mathrm{Sn}_{22}$ $\mathrm{Bi}_{50} \mathrm{~Pb}_{22} \mathrm{Sn}_{28}$ and $\mathrm{Bi}_{50} \mathrm{~Pb}_{16} \mathrm{Sn}_{34}$ alloys. These alloys (mixed metals by weight percentage) are melted and then normal casted on substrate. The samples are prepared in convenient shape for all tests. Microstructure for alloys is performed using Shimadzu X-ray Diffractometer, (Dx-30, Japan) Cu-Ka radiation with I=1.54056 $\AA$ at $45 \mathrm{kV}$ and $35 \mathrm{~mA}$ and $\mathrm{Ni}$-filter, in the angular range $2 \mathrm{q}$ ranging from 0 to $100^{\circ}$ in continuous mode with a scan speed $5 \mathrm{deg} / \mathrm{min}$. The differential scanning calorimetry (DSC) thermographs are obtained by Universal V4. 5A TA Instrument with heating rate $10 \mathrm{k} / \mathrm{min}$ in the temperature range $0-400{ }^{\circ} \mathrm{C}$. Micro-hardness test of used specimens were conducted using a digital Vickers micro-hardness tester, (Model FM-7, Tokyo, Japan), applying a load of $100 \mathrm{gm}$ for 5 seconds via a Vickers diamond pyramid. Ten measurements were recorded for each sample and then the mean value of all measurements was used. The internal friction and dynamic elastic modulus measurements of used samples were carried out with the modified dynamic resonance, which vibrates electro dynamically and is based on a standing-wave phenomenon [17-20].

\section{Results and discussion}

\subsection{Microstructure}

\section{X-ray analysis}

Figure 1 shows $x$-ray diffraction patterns of $\mathrm{Bi}_{50} \mathrm{~Pb}_{34} \mathrm{Sn}_{16}, \mathrm{Bi}_{50} \mathrm{~Pb}_{28} \mathrm{Sn}_{22}, \mathrm{Bi}_{50} \mathrm{~Pb}_{22} \mathrm{Sn}_{28}$ and $\mathrm{Bi}_{50} \mathrm{~Pb}_{16} \mathrm{Sn}_{34}$ alloys. From x-ray diffraction patterns, $\mathrm{Bi}_{50} \mathrm{~Pb}_{34} \mathrm{Sn}_{16}, \mathrm{Bi}_{50} \mathrm{~Pb}_{28} \mathrm{Sn}_{22}, \mathrm{Bi}_{50} \mathrm{~Pb}_{22} \mathrm{Sn}_{28}$ and $\mathrm{Bi}_{50} \mathrm{~Pb}_{16} \mathrm{Sn}_{34}$ alloys have sharp lines of rhombohedral crystals of bismuth, body-centered tetragonal tin, body-centered tetragonal bismuth-tin (agree with the results of $[21,22]$ and hexagonal crystal of $\mathrm{Bi}_{3} \mathrm{~Pb}_{7}$ inter-metallic compound which is agree with the 
results show by Kil-Won Moon et al [23]. The $x$-ray analysis show that, feature for formed phases such as crystallinity (peak intensity), crystal size (peak broadness) and orientations (peak position, $2 \theta$ ) for $\mathrm{Bi}_{50} \mathrm{~Pb}_{34} \mathrm{Sn}_{16}$ $\mathrm{Bi}_{50} \mathrm{~Pb}_{28} \mathrm{Sn}_{22}, \mathrm{Bi}_{50} \mathrm{~Pb}_{22} \mathrm{Sn}_{28}$ and $\mathrm{Bi}_{50} \mathrm{~Pb}_{16} \mathrm{Sn}_{34}$ changed due to modified structure (increased $\mathrm{Sn}$ content with deceased $\mathrm{Pb}$ content). That is because these atoms dissolved in matrix alloy formed a solid solution and $\backslash$ or undetected phases
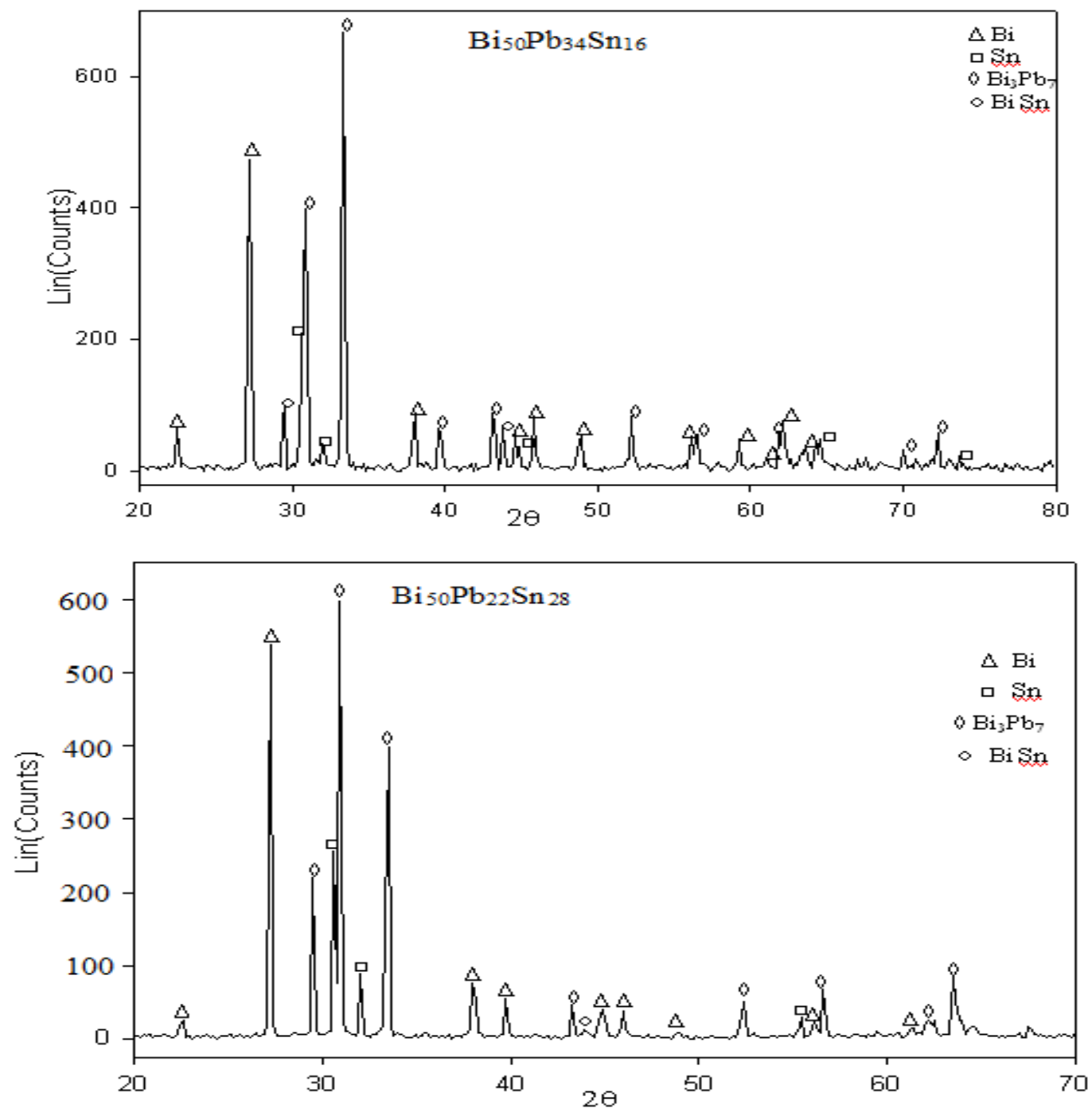


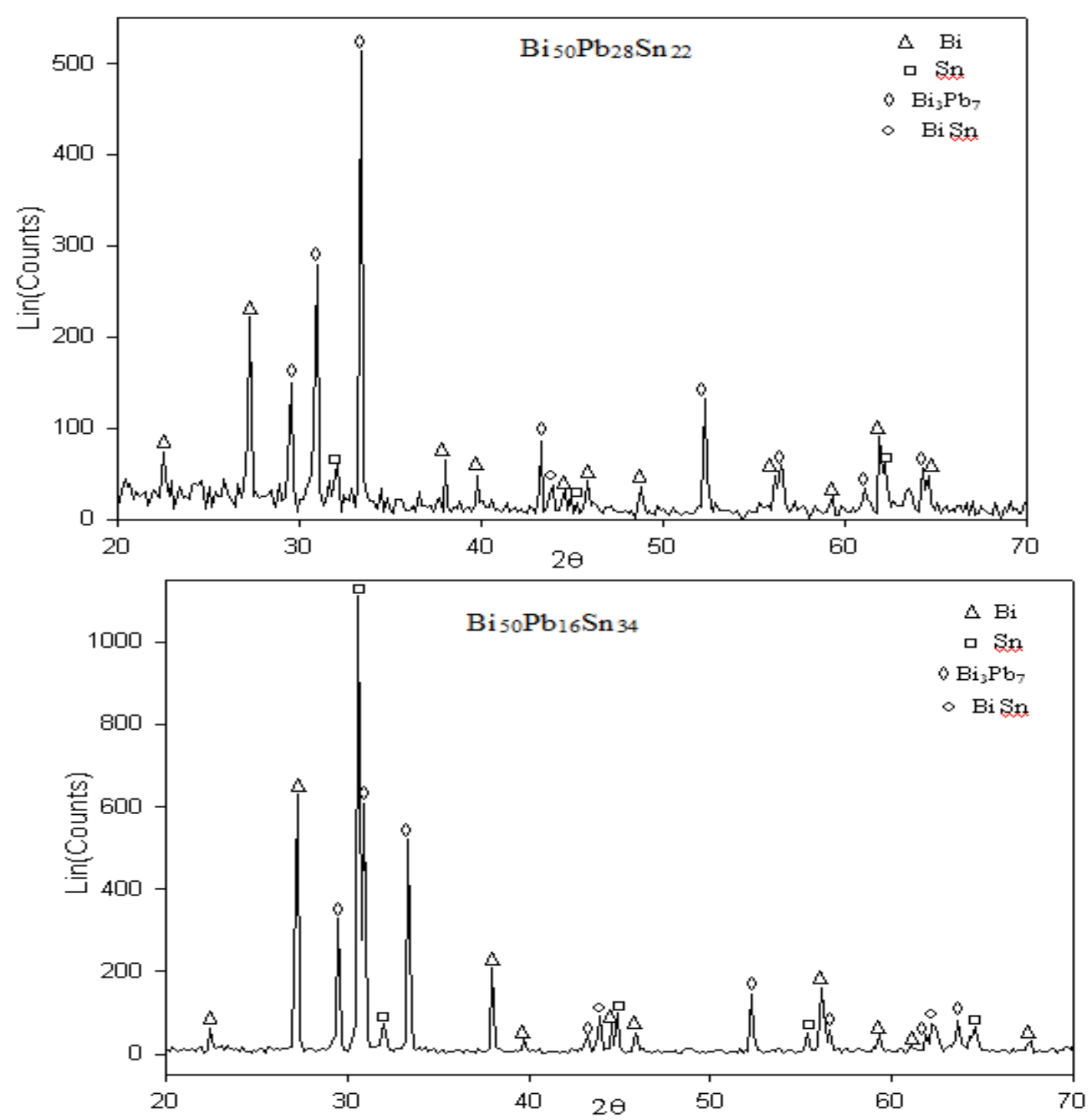

Figure 1: x-ray diffraction patterns of bismuth based alloys

\section{Thermal properties}

Thermal analysis depend on the nature of solid phase and on its temperature. It is used to study solid state transformations as well as solid liquid reactions. The DSC thermographs are obtained with heating rate $10^{\circ} \mathrm{C}$ $/ \mathrm{min}$ in the temperature range $0-400{ }^{\circ} \mathrm{C}$. The melting temperature of $\mathrm{Bi}_{50} \mathrm{~Pb}_{34} \mathrm{Sn}_{16}, \mathrm{Bi}_{50} \mathrm{~Pb}_{28} \mathrm{Sn}_{22}, \mathrm{Bi}_{50} \mathrm{~Pb}_{22} \mathrm{Sn}_{28}$ and $\mathrm{Bi}_{50} \mathrm{~Pb}_{16} \mathrm{Sn}_{34}$ alloys is presented in Table 1, which is dependent on its composition.

Table 1: melting temperature of bismuth based alloys

\begin{tabular}{|l|l|}
\hline Alloys & Melting point ${ }^{\circ} \mathrm{C}$ \\
\hline $\mathrm{Bi}_{50} \mathrm{~Pb}_{34} \mathrm{Sn}_{16}$ & 97 \\
\hline $\mathrm{Bi}_{50} \mathrm{~Pb}_{28} \mathrm{Sn}_{22}$ & 95 \\
\hline $\mathrm{Bi}_{50} \mathrm{~Pb}_{22} \mathrm{Sn}_{28}$ & 94 \\
\hline
\end{tabular}

\section{Internal friction}

The internal friction is determined from the resonance peak-width technique which is preferred than the other method of free decay curve which suitable for low values of internal friction. The internal friction value $\mathrm{Q}^{-1}$ of $\mathrm{Bi}$ based alloys, listed in Table 2, is affected by the alloy composition. That means, it is sensitive to the internal structure (mobile atoms in the matrix which increase or decrease the resonance frequency and the motion time). 
Table 2: internal friction of bismuth based alloys

\section{Vickers hardness}

\begin{tabular}{|l|l|}
\hline Alloys & Internal friction $\left(\mathrm{Q}^{-1}\right)$ \\
\hline $\mathrm{Bi}_{50} \mathrm{~Pb}_{34} \mathrm{Sn}_{16}$ & $66 \pm 3.22$ \\
\hline $\mathrm{Bi}_{50} \mathrm{~Pb}_{28} \mathrm{Sn}_{22}$ & $68.68 \pm 1.72$ \\
\hline $\mathrm{Bi}_{50} \mathrm{~Pb}_{22} \mathrm{Sn}_{28}$ & $88.86 \pm 7.43$ \\
\hline $\mathrm{Bi}_{50} \mathrm{~Pb}_{16} \mathrm{Sn}_{34}$ & $94 \pm 3.58$ \\
\hline
\end{tabular}

Table 3 shows Vickers hardness value for $\mathrm{Bi}_{50} \mathrm{~Pb}_{34} \mathrm{Sn}_{16}, \mathrm{Bi}_{50} \mathrm{~Pb}_{28} \mathrm{Sn}_{22}, \mathrm{Bi}_{50} \mathrm{~Pb}_{22} \mathrm{Sn}_{28}$ and $\mathrm{Bi}_{50} \mathrm{~Pb}_{16} \mathrm{Sn}_{34}$ alloys. It is increased by increasing tin content with decreasing lead content that means the hard inclusions in the matrix surface increased.

Table 3: Vickers hardness of bismuth based alloys

\section{Elastic modulus}

\begin{tabular}{|l|l|}
\hline Alloys & $\begin{array}{l}\text { Vickers hardness } \\
(\mathrm{HV}) \mathrm{Kg} / \mathrm{mm}^{2}\end{array}$ \\
\hline $\mathrm{Bi}_{50} \mathrm{~Pb}_{34} \mathrm{Sn}_{16}$ & $10.7 \pm 0.83$ \\
\hline $\mathrm{Bi}_{50} \mathrm{~Pb}_{28} \mathrm{Sn}_{22}$ & $11.1 \pm 0.43$ \\
\hline $\mathrm{Bi}_{50} \mathrm{~Pb}_{22} \mathrm{Sn}_{28}$ & $12.79 \pm 1.1$ \\
\hline $\mathrm{Bi}_{50} \mathrm{~Pb}_{16} \mathrm{Sn}_{34}$ & $14.79 \pm 1.54$ \\
\hline
\end{tabular}

Elastic modulus value for $\mathrm{Bi}_{50} \mathrm{~Pb}_{34} \mathrm{Sn}_{16}, \mathrm{Bi}_{50} \mathrm{~Pb}_{28} \mathrm{Sn}_{22}, \mathrm{Bi}_{50} \mathrm{~Pb}_{22} \mathrm{Sn}_{28}$ and $\mathrm{Bi}_{50} \mathrm{~Pb}_{16} \mathrm{Sn}_{34}$ alloys decreased by increasing Sn content and decreasing $\mathrm{Pb}$ content as listed in Table 4. It is increased by increasing tin content with decreasing lead content that means the hard inclusions in the matrix surface increased.

Table 4: Elastic modulus of bismuth based alloys

\section{Conclusion}

\begin{tabular}{|l|l|}
\hline Alloys & Elastic modulus (E) \\
\hline $\mathrm{Bi}_{50} \mathrm{~Pb}_{34} \mathrm{Sn}_{16}$ & $16.86 \pm 1.1$ \\
\hline $\mathrm{Bi}_{50} \mathrm{~Pb}_{28} \mathrm{Sn}_{22}$ & $15.379 \pm 0.76$ \\
\hline $\mathrm{Bi}_{50} \mathrm{~Pb}_{22} \mathrm{Sn}_{28}$ & $14.65 \pm 0.41$ \\
\hline
\end{tabular}

In this work lead content in used alloys decreased by $53 \%$, that's mean the toxicity decreased, healthy environmental, for industrial applications. Internal friction and Vickers hardness increased but elastic modulus decreased for bismuth based alloys at tin increase with lead decrease.

\section{References}

[1] M.T. McCormack, Y. Degani, H.S. Chen, W.R. Gesick, J. JOM, 48 (1996) 54

[2] I. Manna and S.K.Pabi, Phys. Status Solidi A, 123 (1991) 393

[3] J. Perkins and G.R. Edwards, J. Mater. Sci., 10 (1975) 136

[4] C.R .Blackwell and K.D. Andmunson, Med. Dosimetry, 15 (1990) 127

[5] A.B. El-Bediwi, S. Bader, F. Khalifa, Global Journal of Physics, 4: 3 (2016) 480

[6] A.B. El-Bediwi, S. Bader, F. Khalifa, IJSRSET, 2: 2 (2016) 1267 
[7] A.B. El-Bediwi and M.M. El-Bahay, Radiat. Effect Defects Solids 159 (2004) 133

[8] M. Kamal and A.B. El-Bediwi, Radiat. Effect Defects Solids, 159 (2004) 651

[9] A.B. El-Bediwi, E. Said Gouda and M. Kamal, A.M.S.E, Modeling C, 65 (1) 2004

[10] A.B. El-Bediwi, M.M. El-Bahay and M. Kamal, Radiat. Effect Defects Solids 159 (2004) 491

[11] M. Kamal, M.B. Karman and A.B. El-Bediwi, U. Scientist Phyl. Sci. 9: 2 (1997) 164

[12] M. Kamal, A.B. El-Bediwi and M.B. Karman, J. Mater. Sci.: Mater. Elect. 9 (1998) 425

[13] A.B. El-Bediwi, A.M.S.E. 75: 3(2002) 1

[14] M. Kamal, M. El-Tonsy, A.B. El-Bediwi et al., Phys. Stat. Sol. (a) 201: 9 (2004) 2029

[15] M. Kamal, A.B. El-Bediwi and T. El-Ashram, J. Mater. Sci. Mater. Electr. 15 (2004) 211

[16] M. Kamal, M.S. Meikhail, A.B. El- Bediwi et al., Radiat. Effect Defects Solids 160: 37 (2005)

[17] E. Schreiber, O.L. Anderson, N. Soga, in Elastic Constant and their Measurements (McGraw-Hill, New York, (1973), pp.82-125

[18] S. Timoshenko and J.N. Goodier, in Theory of elasticity, 2nd ed. (McGraw-Hill, New York, 1951) p.277

[19] K. Nuttall, J. Inst. Met. 99 (1971) 266

[20] C. Zener, in Theory of $D_{0}$ for atomic diffusion in metals, J. Appl. Phys. 22 (1951) 372

[21] R.H. Kane, B.C. Gleissen, N.J. Grant. Acta Metall, 14 (1966) 605

[22] V. Bhattacharya, E. Yamasue, K.N. Ishihara, K. Chattopadhyay, Acta Metall, 53 (2005) 4593

[23] K.W. Moon, W. J. Boettinger, U.R. Kattner, C.A. Handwerker and D.J. Lee, J. Electron. Mater. 30 (2001) 45 